\title{
Thermal stability of extracellular hemoglobin of Rhinodrilus alatus (HbRa): DLS and SAXS studies
}

\author{
José Wilson P. Carvalho ${ }^{2}$ Francisco A. O. Carvalho ${ }^{1}$ Patrícia S. Santiago $^{3} \cdot$ \\ Marcel Tabak ${ }^{1}$
}

Received: 25 July 2015 / Revised: 2 February 2016 / Accepted: 20 February 2016 / Published online: 26 March 2016

(C) European Biophysical Societies' Association 2016

\begin{abstract}
Oxy-HbRa thermal stability was evaluated by dynamic light scattering (DLS) and small-angle X-ray scattering (SAXS) at pH 5.0, 7.0, 8.0, and 9.0. DLS results show that oxy-HbRa, at $\mathrm{pH} 7.0$ and 5.0, remains stable up to $56{ }^{\circ} \mathrm{C}$, undergoing denaturation/aggregation in acidic media above $60{ }^{\circ} \mathrm{C}$, followed by partial sedimentation of aggregates. At alkaline $\mathrm{pH}$ values 8.0 and 9.0, oxy-HbRa oligomeric dissociation is observed above $30{ }^{\circ} \mathrm{C}$, before denaturation. SAXS data show that oxy-HbRa, at $20{ }^{\circ} \mathrm{C}$, is in its native form, displaying radius of gyration $\left(R_{\mathrm{g}}\right)$ and particle maximum dimension $\left(D_{\max }\right)$ of $108 \pm 1$ and $300 \pm 10 \AA$, respectively. Oxy-HbRa, at $\mathrm{pH} 7.0$, undergoes denaturation/aggregation at $60{ }^{\circ} \mathrm{C}$. At $\mathrm{pH} 5.0-6.0$, HbRa thermal denaturation/aggregation start earlier, at $50{ }^{\circ} \mathrm{C}$, accompanied by an increase of $R_{\mathrm{g}}$ and $D_{\max }$ values. However, an overlap of oligomeric dissociation and denaturation in the system is observed upon temperature increase, with an increase in $R_{\mathrm{g}}$ and $D_{\max }$. Analysis of experimental $p(r)$ curves as a linear combination of theoretical curves obtained for $\mathrm{HbGp}$ fragments from the crystal structure shows an increasing contribution of dodecamer $(a b c d)_{3}$ and tetramer $(a b c d)$ in solution, as a function of $\mathrm{pH}$ values $(8.0$ and 9.0) and temperature. Finally, our data show, for the
\end{abstract}

Electronic supplementary material The online version of this article (doi:10.1007/s00249-016-1121-6) contains supplementary material, which is available to authorized users.

\footnotetext{
José Wilson P. Carvalho

jwilsonc@unemat.br

Instituto de Química de São Carlos, SP, Brazil

2 Universidade do Estado de Mato Grosso, Barra do Bugres, MT, Brazil

3 Universidade Estadual Paulista Júlio de Mesquita Filho, Registro, SP, Brazil
}

first time, that oxy-HbRa, in neutral and acidic media, does not undergo oligomeric dissociation before denaturation, while in alkaline media the oligomeric dissociation process is an important step in the thermal denaturation.

Keywords Erythrocruorins - Thermal stability · Denaturation/aggregation · Oligomeric dissociation $\cdot \mathrm{pH}$

\section{Introduction}

The Rhinodrilus belongs to the class Oligochaeta, one of the three classes of Annelida phylum. Annelids present great diversity, occurring in diverse environments, from marine to terrestrial (Desbruye and Laubier 1982; Lamy et al. 1996; Weber and Vinogradov 2001); however, all specimens have a giant extracellular hemoglobin hexagonal-bilayer, with a molecular mass of about 3 MDa (Bachega 2013; Carvalho et al. 2014a, b; Oliveira et al. 2007; Royer et al. 2005, 2006; Rousselot et al. 2006; Tabak et al. 2012). The Rhinodrilus alatus (HbRa) extracellular hemoglobin is a giant protein with a complex oligomeric structure, presenting 144 globin chains and 36 chains lacking the heme group (named linkers), with a total molecular mass of $3.5 \mathrm{MDa}$ (Carvalho et al. 2014a, b; Tabak et al. 2012), and possessing a characteristic quaternary architecture, namely the hexagonal-bilayer structure. In Scheme 1, the HbGp hierarchical oligomeric organization is represented. The whole HbGp structure is composed by an hexagonal-bilayer of 12 protomers, each corresponding to $(a b c d)_{3} L_{3}$. The hexagonal monolayer is composed of $6(a b c d)_{3} L_{3}$, the dodecamer corresponds to $(a b c d)_{3}$ and the tetramer is formed by four different monomeric globin chains $(a, b, c$ and $d$ ), where $a, b$, and $c$ globin chains are linked by disulfide bridges forming a trimer and a monomer $d$ (Scheme 1). 
Scheme 1 Structural hierarchy of $\mathrm{HbGp}$

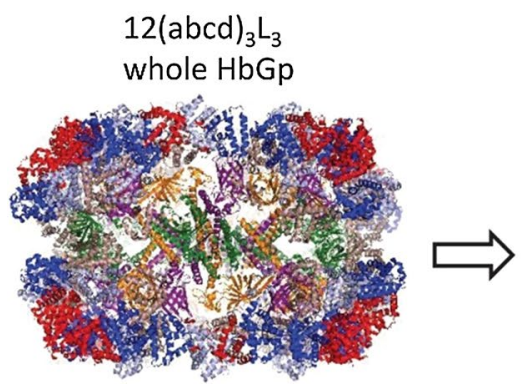

Side view

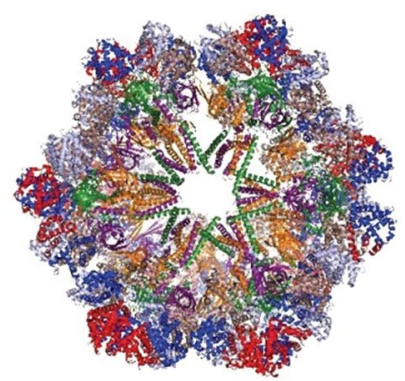

Top view

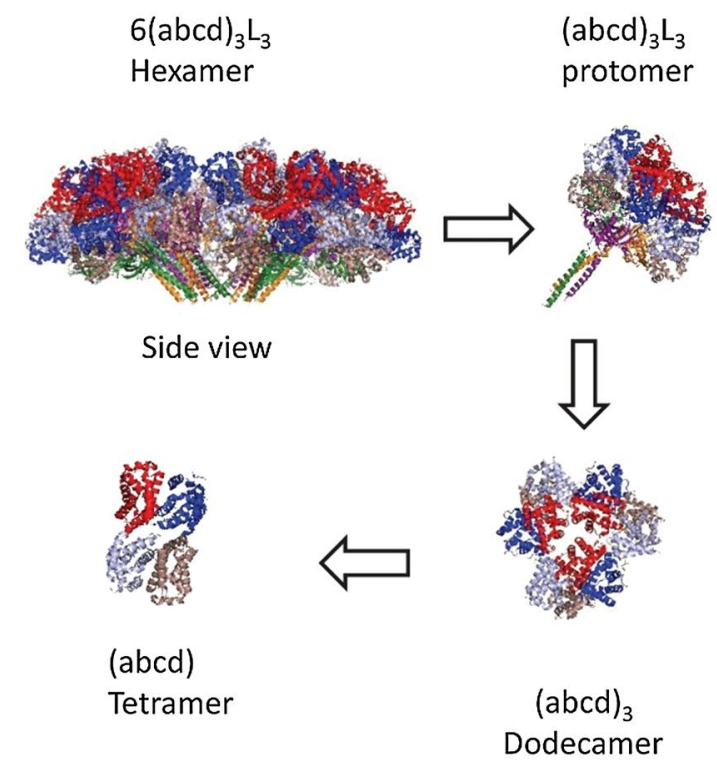

6(abcd $)_{3} \mathrm{~L}_{3} \quad(\mathrm{abcd})_{3} \mathrm{~L}_{3}$ Hexamer protomer

Dodecamer
Spectroscopic, hydrodynamic, and crystallographic studies suggest that HbRa hemoglobin belongs to the same type as the extracellular hemoglobins of Glossoscolex paulistus (HbGp) and Lumbricus terrestris (HbLt) (Bachega et al. 2011; Bachega 2013; Carvalho et al. 2014a, b; Oliveira et al. 2007; Royer et al. 2005, 2006; Tabak et al. 2012). HbLt and HbGp are the most extensively studied giant hemoglobins (Bachega et al. 2011; Carvalho et al. 2012, 2013, 2015; Krebs et al. 1998; Oliveira et al. 2007; Poli et al. 2005; Royer et al. 2005, 2006; Rousselot et al. 2006; Santiago et al. 2008, 2010a, b). Another widely studied giant protein is Arenicola marina hemoglobin (HbAm), orthologous of $\mathrm{HbGp}$ and $\mathrm{HbLt}$, presenting quite similar hierarchic structural organization and biophysical properties (Zal and Rousselot 2014; Jernshøj et al. 2013). These hemoglobins present high cooperativity in oxygen binding and high resistance to the oxidation process as compared to human hemoglobin (Poli et al. 2005; Santiago et al. 2008). Due to these properties and the fact that they are extracellular hemoglobins with large size, HbLt and HbAm have been considered as a promising model system for developing therapeutic blood substitutes (artificial blood; Zal and Rousselot 2014).

MALDI-TOF-MS studies have shown that HbRa displays a tetramer $(a b c d)$ with a molecular mass of $67,690 \mathrm{Da}$, an hetero-trimer $(a b c)$ of 51,479 $\mathrm{Da}$, where the $a, b$ and $c$ subunits are linked by disulfide bonds, and different linkers chains $L\left(L_{1}, L_{2}, L_{3}\right.$, and $\left.L_{4}\right)$ with molecular masses in the range of 25,970-32,515 Da (Carvalho et al. 2014a; Tabak et al. 2012). In the presence of 2-mercaptoethanol reducing agent, four different monomer subunits are observed, $a, b, c$ and $d$ with molecular masses in the range of 16,166-17,133 Da (Carvalho et al. 2014a; Tabak et al. 2012). At least four isoforms for monomer $d$ are observed, with molecular masses in the range of 16,272-16,710 Da. Moreover, SDS-PAGE electrophoresis studies show a band pattern for oxy-HbRa, consisting of trimer, linkers $\left(L_{1}, L_{2}, L_{3}\right.$, and $\left.L_{4}\right)$, and in the presence of 2-mercaptoethanol reducing agent, monomers $a, b, c$, and $d$ subunits are observed (Bachega 2013; Carvalho et al. 2014a, b; Vinogradov 2004). These band patterns SDSPAGE electrophoresis are similar to those reported for HbGp (Carvalho et al. 2011; Tabak et al. 2012).

Previous studies show an absorption spectrum for oxy$\mathrm{HbRa}$, at $\mathrm{pH} 7.0,25{ }^{\circ} \mathrm{C}$, with a Soret band centered at $416 \mathrm{~nm}$ and two Q-bands at 540 and $575 \mathrm{~nm}$, quite similar to oxy-HbGp (Carvalho et al. 2014a; Poli et al. 2005; Santiago et al. 2010b). Above pH 8.0, a decrease of Soret band intensity together with a blue shift is observed, assigned to the oxidation of $\mathrm{Fe}^{2+}$ (reduced state of iron for native protein) to $\mathrm{Fe}^{3+}$ (oxidized state of iron, protein in aquamet form). Moreover, studies based on the fluorescence, light scattering intensity (LSI), and analytical ultracentrifugation are consistent with oxy-HbRa oligomeric dissociation at alkaline pH media (Carvalho et al. 2014a; Tabak et al. 2012).

As investigated by Zal et al. (2000, 2014), this diversity justifies the study of extracellular hemoglobin in different species of annelids. To evaluate different hemoglobin species is an interesting question, to test whether this diversity 
reflects evolutionary divergences or an intrinsic plasticity of the hemoglobin structure. In addition, since to build extracellular hemoglobins different globin and linkers chains are necessary to achieve this particular quaternary architecture, as well as the stability of the oligomeric structure, these studies could allow to assess what are the essential elements for the success (Zal et al. 2000; Zal and Rousselot 2014). Moreover, studies have been reported on some advances on biotechnological HbAm applications with the development of different products, as for example: a preservation organ solution and a restauration oxygenation blood, both based on the Arenicola marina hemoglobin (Zal and Rousselot 2014).

In the current study, HbRa thermal denaturation is focused in the $\mathrm{pH}$ range of 5.0-9.0. Our aim is to evaluate the effect of $\mathrm{pH}$ on the HbRa thermal stability as monitored by dynamic light scattering (DLS) and small-angle X-ray scattering (SAXS). Oxy-HbRa melting studies were performed in acidic, neutral, and alkaline $\mathrm{pH}$ by DLS. Critical dissociation, denaturation, and aggregation temperatures were obtained at different $\mathrm{pH}$ values. SAXS technique was also used to monitor the oxy-HbRa oligomeric structural changes as a function of temperature. SAXS parameters $R_{\mathrm{g}}$, $D_{\text {max }}$ and scattering intensity at $q=0,(I(0))$, were monitored in the $\mathrm{pH}$ range of 5.0-9.0, in the temperature range of $20-60{ }^{\circ} \mathrm{C}$. These studies contribute to the characterization of the $\mathrm{pH}$ effects upon the oxy-HbRa oligomeric stability as a function of temperature.

\section{Materials and methods}

\section{Purification and preparation of $\mathrm{HbRa}$}

Rhinodrilus alatus hemoglobin was prepared using freshly drawn blood from worms as described earlier (Bachega et al. 2011; Bachega 2013; Carvalho et al. 2014a, b; Tabak et al. 2012; Santiago et al. 2010a). The blood sample was centrifuged at $4{ }^{\circ} \mathrm{C}(2300 \times g$ for $15 \mathrm{~min})$ to eliminate cell debris. An ultra-filtration (molecular mass cut-off of $30 \mathrm{kDa}$ ) in $100 \mathrm{mmol} / \mathrm{l} \mathrm{Tris}-\mathrm{HCl}$ buffer $\mathrm{pH} 7.0$, at $4{ }^{\circ} \mathrm{C}$, was performed in order to eliminate low molecular weight $\left(M_{\mathrm{w}}\right)$ components. After the ultracentrifugation at $250,000 \times g$, at $4{ }^{\circ} \mathrm{C}$, during $3 \mathrm{~h}, \mathrm{HbRa}$ was obtained as a pellet. It was re-suspended in a minimum amount of $100 \mathrm{mmol} / \mathrm{l}$ Tris$\mathrm{HCl}$ buffer $\mathrm{pH} 7.0$ and stored in the oxy-HbRa form at $4{ }^{\circ} \mathrm{C}$. The final purification step was the filtration through a Sephadex G-200 chromatography column, where pure oxy-HbRa is obtained in the void volume of the column. In the oxy-HbRa sample preparations for all studies described in this paper, an optical absorption spectrum in the UV/ Vis region (250-700 nm) was collected. This HbRa optical absorption spectrum shows a Soret band at $415 \mathrm{~nm}$ and
two-Q bands at 535 and $575 \mathrm{~nm}$, respectively, very characteristic of oxy-HbRa. A similar spectrum for oxy-HbRa is reported in the reference (Carvalho et al. 2014a). Additionally, native oxy-HbRa has a very sharp single DLS peak, characteristic of a monodisperse single particle system with $27 \mathrm{~nm}$ hydration diameter. Again, this is quite characteristic for the whole native protein. HbRa does not aggregate, and remains soluble and stable in Tris- $\mathrm{HCl} 100 \mathrm{mmol} / \mathrm{l}$ buffer solution for a long time (around 1 year). Both DLS and ultracentrifugation studies confirm that pure oxy-HbRa remains as the native whole protein of around $3600 \mathrm{kDa}$ and sedimentation coefficient around $58 \mathrm{~S}$. All concentrations were determined spectrophotometrically in a UV-1601 PC spectrophotometer (Shimadzu, Japan), using the known molar extinction coefficient of orthologous oxy$\mathrm{HbGp}$ of $\varepsilon_{415 \mathrm{~nm}}=5.5 \pm 0.8(\mathrm{mg} / \mathrm{ml})^{-1} \mathrm{~cm}^{-1}$ (Santiago et al. 2010a).

\section{Dynamic light scattering (DLS) measurements}

Zetasizer Nano ZS (Malvern, UK) was used for the light scattering measurements. This instrument allows dynamic light scattering measurements incorporating noninvasive backscattering (NIBS) optics. A He-Ne laser is used as the light source with a wavelength $\lambda=633 \mathrm{~nm}$. The intensity of light, scattered at an angle of $173^{\circ}$, is monitored by an avalanche photodiode (Pecora 1985; Santiago et al. 2008).

Initially, oxy-HbRa $20 \mathrm{mg} / \mathrm{ml}$ stock solution was dialyzed in acetate-borate-phosphate buffer $30 \mathrm{mmol} / \mathrm{l}$ for $6 \mathrm{~h}$, at $4{ }^{\circ} \mathrm{C}$, and the protein concentration was re-measured. All samples were prepared by dilution of the previously dialyzed concentrated stock solution in the same buffer. The DLS measurements were performed for oxy-HbRa $3.0 \mathrm{mg} /$ $\mathrm{ml}$, in the $\mathrm{pH}$ range of 5.0-9.0, at temperatures between 20 and $70{ }^{\circ} \mathrm{C}$, controlled with an accuracy of $0.1^{\circ} \mathrm{C}$. The DLS data were collected by increasing the sample temperature by $1^{\circ} \mathrm{C}$ over $1 \mathrm{~min}$, followed by equilibration for 5 min, and then 7 data points were collected at each temperature. Depending on the scattering intensity the measurement time was variable, but all the samples were heated for a long time, around $20 \mathrm{~h}$, to complete the heating cycle. The melting curves for oxy-HbRa were analyzed based on the samples hydrodynamic diameter $\left(D_{\mathrm{H}}\right)$ value, the critical denaturation temperature $\left(T_{\mathrm{den}}\right)$, the scattering particle size intensity and particle number distributions and the peak width at half height for intensity distribution curves. The analyses were performed using Malvern's DTS 6.01 software. The intensity and particle number size distributions curves were obtained directly from the primary data. Another important parameter obtained by the DLS measurement is the scattering intensity (kcounts/s) due to its high sensitivity to the size changes of the species in solution, allowing a good characterization of aggregation, 
denaturation and oligomeric dissociation processes for oligomeric proteins.

\section{Small-angle X-ray scattering (SAXS) measurements}

Oxy-HbRa $20 \mathrm{mg} / \mathrm{ml}$ stock solution was dialyzed in acetatephosphate-borate $30 \mathrm{mmol} / \mathrm{l}$ buffer for $6 \mathrm{~h}$ to equilibrate the used $\mathrm{pH}$ values (acidic, neutral, and alkaline media). After this initial dialysis, the protein concentration was checked spectrophotometrically, as described in the "Purification and preparation of HbRa" section. All samples were prepared by dilution of previously dialyzed oxy-HbRa concentrated stock solution. Protein solutions at $3.0 \mathrm{mg} / \mathrm{ml}$ were measured as a function of temperature and $\mathrm{pH}$ values for $90 \mathrm{~s}$ of exposure time and recorded in a two-dimensional position-sensitive detector MARCCD. The measurements were initially performed for all samples at $20{ }^{\circ} \mathrm{C}$. A commercial water bath was set in the sequence to $40{ }^{\circ} \mathrm{C}$ and again all samples were measured at this temperature. Further, each isolated sample was submitted to heating in a sequence to 50 and $60{ }^{\circ} \mathrm{C}$, and after measuring at these two temperatures, it was cooled back down to $20^{\circ} \mathrm{C}$, followed by cleaning of sample compartment and insertion of a new sample. Each sample was equilibrated for $10 \mathrm{~min}$ at each temperature before measurement. The SAXS curves for buffer solutions were subtracted from the HbRa solution SAXS curves before analysis.

In this study, we made use of the GNOM program (Mertens and Svergun 2010) to calculate $p(r)$ functions directly from the scattering curves, and the respective $R_{\mathrm{g}}$, $D_{\max }$ and $I(0)$ parameter values. The analysis by GNOM is an important first approximation approach to obtain relevant structural information on the macromolecule in the real space directly from the scattering curve without the need for more detailed previous knowledge (Hirai et al. 1999; Mertens and Svergun 2010; Putnam et al. 2007; Svergun 1991). Besides, for monodisperse systems, a Fourier transform connects the scattering intensity $I(\mathrm{q})$ to the pair distance distribution function, $p(r)$, which is related to the probability of finding a pair of small particle volumes at a distance $r$ within the entire volume of the scattering particle. These structural analyses are valid only for particles with homogeneous electron density (non-interacting systems). In the case of interaction between molecules, as for example hemoglobin molecules (aggregates formation), this hypothesis is not strictly valid and can be considered only as a first approximation and for qualitative comparison. In this current study, the radius of gyration $\left(R_{\mathrm{g}}\right)$ parameter was also obtained by Guinier approximation (Guinier and Fournet 1955). In this case, for a monodisperse solution of globular protein the Guinier approximation is described by $I(q \rightarrow 0)=I(0) \exp \left(-\left(R_{g}^{2} q^{2}\right)^{1 / 3}\right)$ where $I(0)$ and $R_{\mathrm{g}}$ are determined from the $y$-axis intercept and the slope of the linear plot of $\ln I(q)$ versus $q^{2}$ (Guinier and Fournet 1955).
Furthermore, Kratky plots that are defined as the dependences of $I(q)^{*} q^{2}$ on $q$, were also used to monitor the protein unfolding process. Folded globular proteins display a defined peak at lower $q$ values, showing a bell-shaped Kratky plot. However, unfolded proteins show a continuous decrease in $I(q) * q^{2}$ versus $q$, in the low $q$ range below 0.1 and $0.2 \AA^{-1}$ (Glatter and Kratky 1982; Mertens and Svergun 2010). Therefore, the Kratky plot is a good representation to observe conformational changes of the protein in solution induced, for instance, by the temperature, $\mathrm{pH}$ changes and presence of denaturant agents (Carvalho et al. 2014b; Mertens and Svergun 2010; Putnam et al. 2007).

Moreover, a non-linear fitting, based on the Origin 8.0 software from Microcal, was also performed, aiming to simulate the $p(r)$ functions corresponding to the experimental oxyHbRa SAXS curves at different temperatures and $\mathrm{pH}$ values as a linear combination (superposition) of $p(r)$ functions derived for several fragments of the whole protein crystallographic structure that was very recently reported for $\mathrm{HbGp}$ (Bachega et al. 2015). The scattering curves for the fragments were prepared from $\mathrm{HbGp}$ crystal structure (PDB under ID code 4U8U; Bachega et al. 2015) by using the CRYSOL software (Konarev et al. 2006). The use of oxy-HbGp structure as a model for oxy-HbRa, both in the native form and in the smaller fragments, seems reasonable since both proteins present a similar mass of 3.6 MDa. They also probably have an oligomeric dissociation equilibrium involving the co-existence of multiple species and similarity in structure (Carvalho et al. 2014a, b). We believe that this simulation (fit) in the $r$-space is more intuitive to monitor the size changes, especially involved in protein dissociation and/or aggregation. In addition, fits by OLIGOMER package (Konarev et al. 2006) were performed for oxy-HbRa $I(q)$ experimental curves. The initial guess for the oligomer fits was based on previously obtained results by non-linear fitting for $p(r)$ functions.

\section{Results and discussion}

\section{Oxy-HbRa thermal stability in the pH range of 5.0-9.0 by DLS}

\section{Melting curves and intensity count rates}

In Fig. 1, the melting curves obtained by heating oxy-HbRa solution in the range of $20-70{ }^{\circ} \mathrm{C}$ are presented. Figure 1a, b show the hydrodynamic diameter $\left(D_{\mathrm{H}}\right)$, while Fig. $1 \mathrm{c}, \mathrm{d}$ present the intensity count rate in the $\mathrm{pH}$ range of 5.0-9.0. The corresponding hydrodynamic and thermal parameters are displayed in Table 1. Our data show that, oxy-HbRa, at $20{ }^{\circ} \mathrm{C}$, is in the native form, at $\mathrm{pH} 5.0,7.0$, and 8.0, with

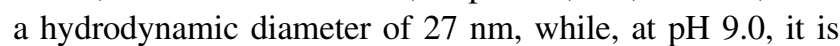
partially dissociated with $D_{\mathrm{H}}$ of $25 \mathrm{~nm}$ (Table 1). Previous 
Fig. 1 a, b Oxy-HbRa hydrodynamic diameter $D_{\mathrm{H}}(\mathrm{nm})$, and c, d intensity (kcounts/s) plots, as a function of temperature. Oxy-HbRa, at $3.0 \mathrm{mg} / \mathrm{ml}$, in phosphate-acetate-borate buffer $30 \mathrm{mmol} / \mathrm{l}$, in the $\mathrm{pH}$ range of 5.0-9.0. The insets for $D_{\mathrm{H}}(\mathrm{nm})$ and intensity (kcounts/s) versus temperature highlight the range between 50 and $65^{\circ} \mathrm{C}(\mathrm{a})$, and 50 and $60{ }^{\circ} \mathrm{C}(\mathbf{c})$, to show the denaturation and aggregation. Intensity is in kilocounts/s (kcounts/s $=10^{3}$ counts $/ \mathrm{s}$ )
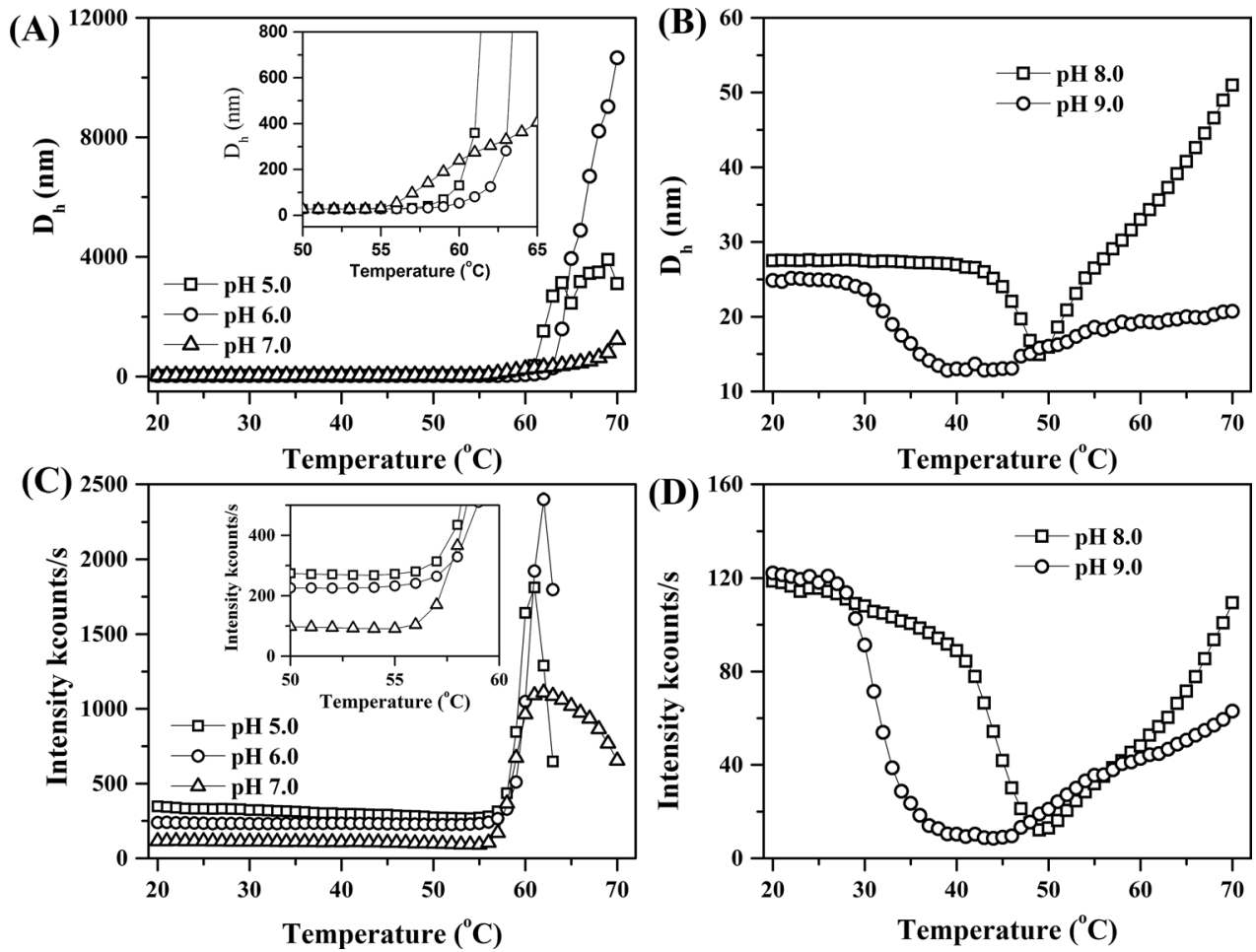

Table 1 Values of sizes and critical temperatures associated with the effects of temperature on oxy-HbRa, in the pH range of 5.0-9.0

\begin{tabular}{lllllll}
\hline [oxy-HbRa], $\mathrm{mg} / \mathrm{ml}$ & $\mathrm{pH}$ & $\left.<D_{\mathrm{H}}\right\rangle_{\text {initial }}(\mathrm{nm})$ & $T_{\text {diss }}\left({ }^{\circ} \mathrm{C}\right)$ & $<D_{\mathrm{H}}>_{\text {dissociated }}(\mathrm{nm})$ & $T_{\text {den }}\left({ }^{\circ} \mathrm{C}\right)$ & $<0 \pm 1$ \\
\hline 3.0 & 5.0 & $27 \pm 1$ & - & - & $62 \pm 1$ & a \\
& 6.0 & $27 \pm 1$ & - & - & $56 \pm 1$ & $1240 \pm 10$ \\
& 7.0 & $27 \pm 1$ & - & - & $51 \pm 1$ & $51 \pm 3$ \\
& 8.0 & $27 \pm 1$ & $43 \pm 1$ & $15 \pm 1$ & $45 \pm 1$ & $21 \pm 2$ \\
\hline
\end{tabular}

The parameters are from the data in Fig. 1a, b

$\left\langle D_{\mathrm{H}}\right\rangle_{\text {initial }}(\mathrm{nm})$, Z-average hydrodynamic diameter of oxy-HbRa, at initial temperature $\left(20^{\circ} \mathrm{C}\right)$; $T_{\text {diss }}$ temperature where the Z-average hydrodynamic diameter decreases and $\left\langle D_{\mathrm{H}}\right\rangle_{\text {dissociated }}$ is the smaller $D_{\mathrm{H}}$ value when the protein oligomeric dissociation takes places; $T_{\text {den }}$, critical denaturation temperature, where the Z-average hydrodynamic diameter increases; $\left\langle D_{\mathrm{H}}\right\rangle_{\text {den/agg }}$, Z-average hydrodynamic diameter at the highest temperature $\left(70^{\circ} \mathrm{C}\right.$, Fig. 1a, b). The reported error values correspond to standard deviation for independent measurements $(n=3)$ by DLS

a $D_{\mathrm{H}}$ values are either above the limiting value for the DLS instrument or the errors are very large, making the exact values for the aggregates not justified

studies for oxy-HbGp show very similar results, and a $D_{\mathrm{H}}$ value of $27 \mathrm{~nm}$ is observed in the $\mathrm{pH}$ range of 5.0-8.0. The scattering intensity strongly depends on the particle volume in solution. Thus, this slight shift of $D_{\mathrm{H}}$ value suggests either a larger contribution from the whole protein or conformational changes of oxy-HbRa oligomeric structure. The partial oligomeric dissociation is also observed, at $\mathrm{pH}$ 9.0, for oxy-HbGp (Santiago et al. 2008). Arenicola marina hemoglobin at $20^{\circ} \mathrm{C}$ also presents similar $D_{\mathrm{H}}$ values to oxy-HbRa in the $\mathrm{pH}$ range of 5.0-7.0. However, at $\mathrm{pH} 8.0$, it is partially dissociated with a hydrodynamic diameter of $15.5 \mathrm{~nm}$, and, at $\mathrm{pH}$ 9.0, $\mathrm{HbAm}$ is completely dissociated, displaying a $D_{\mathrm{H}}$ of $9 \mathrm{~nm}$ (Jernshøj et al. 2013). Thus, our current study indicates that oxy-HbRa has a $\mathrm{pH}$ stability similar to that of oxy-HbGp, being more stable than HbAm. These observed differences on the oligomeric stability towards $\mathrm{pH}$ variation could be due to the differences in the annelids habitat.

Oxy-HbRa, at pH 7.0 (Fig. 1a), remains stable up to $56{ }^{\circ} \mathrm{C}$, maintaining a $D_{\mathrm{H}}$ value of $27 \mathrm{~nm}$ and at higher temperatures the thermal denaturation and aggregation processes are observed (see insert in Fig. 1a). The denaturation and aggregation are characterized by a significant increase in the $D_{\mathrm{H}}$ value, reaching $1240 \pm 10 \mathrm{~nm}$ at $70{ }^{\circ} \mathrm{C}$ (Table 1; Fig. 1a). In the acidic $\mathrm{pH}$ range ( $\mathrm{pH}$ values 5.0 and 6.0), 
oxy-HbRa is more stable, as compared to $\mathrm{pH} 7.0$, undergoing denaturation and aggregation at 60 and $62{ }^{\circ} \mathrm{C}$, respectively (insert in Fig. 1a; Table 1). The thermal denaturation and aggregation produce large aggregates with sizes above the limit of detection of our DLS instrument (around $10 \mu \mathrm{m}$ or $10,000 \mathrm{~nm}$ ). Moreover, the denaturation and aggregation processes are accompanied by a partial sedimentation of aggregates, leading to the fluctuation in the $D_{\mathrm{H}}$ values (Fig. 1a) and a steep decrease in the intensity count rates (Fig. 1c) above $60{ }^{\circ} \mathrm{C}$. Previous studies reported for oxy$\mathrm{HbGp}$ show that the tendency to produce larger aggregates at high temperatures and acidic $\mathrm{pH}$ as well as some partial sedimentation of larger aggregates is due to the proximity of the isoelectric point at $\mathrm{pH} 5.0$ and $6.0(\mathrm{p} I=5.5$; Carvalho et al. 2014b; Santiago et al. 2010a). The present oxy-HbRa results are similar, but not identical to the data reported for its orthologous oxy-HbGp (Carvalho et al. 2015; Santiago et al. 2008, 2010a). Oxy-HbGp, at pH 7.0 and 5.0, undergoes denaturation/aggregation at 52 and $56{ }^{\circ} \mathrm{C}$, respectively (Carvalho et al. 2015; Santiago et al. 2008), while for oxy-HbRa this phenomenon occurs at higher temperatures (Table 1), showing clearly that oxy-HbRa is more stable upon heating. Our DLS data are also in agreement with recent studies, based on optical absorption, fluorescence emission and LSI (light scattering intensity measured at $90^{\circ}$ in the fluorometer), that revealed the oxy-HbRa oligomeric dissociation at $\mathrm{pH}$ values above 8.0 (Carvalho et al. 2014a).

The increase of temperature induces oxy-HbRa partial oligomeric dissociation, starting at 43 and $31{ }^{\circ} \mathrm{C}$, respectively, at $\mathrm{pH}$ values 8.0 and 9.0, with corresponding minimum $D_{\mathrm{H}}(\mathrm{nm})$ for the dissociated species of $15 \mathrm{~nm}$ at $49{ }^{\circ} \mathrm{C}$, and $13 \mathrm{~nm}$ at $38{ }^{\circ} \mathrm{C}$ (Table 1; Fig. 1b). The thermal denaturation of dissociated species is observed at $51{ }^{\circ} \mathrm{C}$, for $\mathrm{pH} 8.0$, following an increase of $D_{\mathrm{H}}$ value to $51 \pm 3 \mathrm{~nm}$, at $70{ }^{\circ} \mathrm{C}$ (Table 1; Fig. 1b). Moreover, at pH 9.0, the oligomeric dissociation process takes place earlier, as compared to $\mathrm{pH}$ 8.0: already at $20^{\circ} \mathrm{C}$, the $D_{\mathrm{H}}$ value is $25 \mathrm{~nm}$ (Table 1; Fig. 1b). The start of dissociation upon heating, at $\mathrm{pH} 9.0$, as noticed in the melting curve, is $12{ }^{\circ} \mathrm{C}$ lower, as compared to $\mathrm{pH} 8.0$, and the $D_{\mathrm{H}}$ value is also slightly lower ( $T_{\text {diss }}$, Table 1). The unfolding of the dissociated species, at $\mathrm{pH}$ 9.0 , is observed in a relatively broad range, around $45^{\circ} \mathrm{C}$, noticed in the melting curve by an increase in the $D_{\mathrm{H}}$ value (Fig. 1b). However, the size of the unfolded species, at $70{ }^{\circ} \mathrm{C}$, at $\mathrm{pH}$ values 8.0 and 9.0 , are significantly smaller, as compared to the value at pH 7.0 (Table 1; Fig. 1a, b). This smaller size of unfolded species, at alkaline $\mathrm{pH}$, is probably due to the oligomeric dissociation process, inhibiting the formation of large aggregates in solution. This behavior is quite similar to that observed for oxy-HbGp (Santiago et al. 2008; Carvalho et al. 2014b).
The scattering intensity (count rates) melting curves, for oxy-HbRa at neutral and acidic $\mathrm{pH}$ values, are similar to the $D_{\mathrm{H}}$ curves without any evidence of partial oligomeric dissociation (Fig. 1c). These results are different as compared to oxy-HbGp, which undergoes a partial oligomeric dissociation before denaturation and aggregation (Carvalho et al. 2014b). It is worth noticing the decrease of intensity (kcounts/s) for oxy-HbRa at $20{ }^{\circ} \mathrm{C}$ due to partial oligomeric dissociation accompanied by a significant decrease in the scattering intensity (Fig. 1c, d). At acidic $\mathrm{pH}$ values 5.0 and 6.0, the sedimentation of aggregates is more evident, leading to larger fluctuations in the intensity counts/s values above $60^{\circ} \mathrm{C}$ (Fig. 1c).

\section{Scattering intensity and particle number distributions}

The scattering intensity and particle number (\%) distributions curves for oxy-HbRa at different $\mathrm{pH}$ and selected (from the melting data) temperatures values are displayed in Fig. 2. At $20^{\circ} \mathrm{C}$, a single contribution in both the scattering intensity and particle number distributions curves, characteristic of native oxy-HbRa in solution, at $\mathrm{pH}$ values 7.0 and 5.0, is observed (Fig. 2a-d). The un-dissociated protein is the single species present in the solution, at $\mathrm{pH} 7.0$, up to $50{ }^{\circ} \mathrm{C}$ (Fig. 2a). At $55{ }^{\circ} \mathrm{C}$, a shift of the intensity curve to $33 \mathrm{~nm}$ is observed (Fig. 2b), indicating the start of protein denaturation. At $65^{\circ} \mathrm{C}$, oxy-HbRa is completely denatured and aggregated, presenting two peaks at 190 and $1040 \mathrm{~nm}$, respectively (Fig. 2a). In the particle number distribution curves, a single peak is observed up to $55{ }^{\circ} \mathrm{C}$, consistent with the intensity curves, and at 60 and $65^{\circ} \mathrm{C}$, a mixture of aggregates with peaks around 35,100 , and $190 \mathrm{~nm}$ is observed (Fig. 2b).

At $\mathrm{pH}$ 5.0, oxy-HbRa also shows intensity distribution curves with a single contribution due to native protein up to $55{ }^{\circ} \mathrm{C}$, while at 60 and $61{ }^{\circ} \mathrm{C}$, a mixture of aggregates of different sizes is observed (Fig. 2c). The corresponding particle number distribution curves present native oxy-HbRa up to $60{ }^{\circ} \mathrm{C}$, suggesting that the amount of aggregates formed in solution is not significant at this temperature. However, at $61{ }^{\circ} \mathrm{C}$, the protein is completely denatured/ aggregated, displaying a broad peak at $230 \mathrm{~nm}$ (Fig. 2b). At $\mathrm{pH}$ 6.0, the intensity and number of distribution curves at $20{ }^{\circ} \mathrm{C}$ (curves not shown) are similar to those at $\mathrm{pH} 5.0$ (Fig. 2c, d). The scattering intensity curves also show the beginning of oxy-HbRa denaturation/aggregation at $60{ }^{\circ} \mathrm{C}$ (curves not shown), while the particle number distribution curves present a decrease in the number of particles, probably due to a partial sedimentation process.

For alkaline $\mathrm{pH}$ 9.0, a broad scattering intensity curve is observed, consistent with the partially dissociated protein, 
Fig. 2 Scattering intensity and particle number distribution curves for oxy-HbRa at $3.0 \mathrm{mg} /$ $\mathrm{ml}$ in phosphate-acetate-borate buffer $30 \mathrm{mmol} / \mathrm{l}$ at different temperatures. a, b At pH 7.0, c, $\mathbf{d}$ at $\mathrm{pH} 5.0$, and $\mathbf{e}, \mathbf{f}$ at $\mathrm{pH} 8.0$, and $\mathbf{g}, \mathbf{h}$ at $\mathrm{pH} 9.0$, respectively
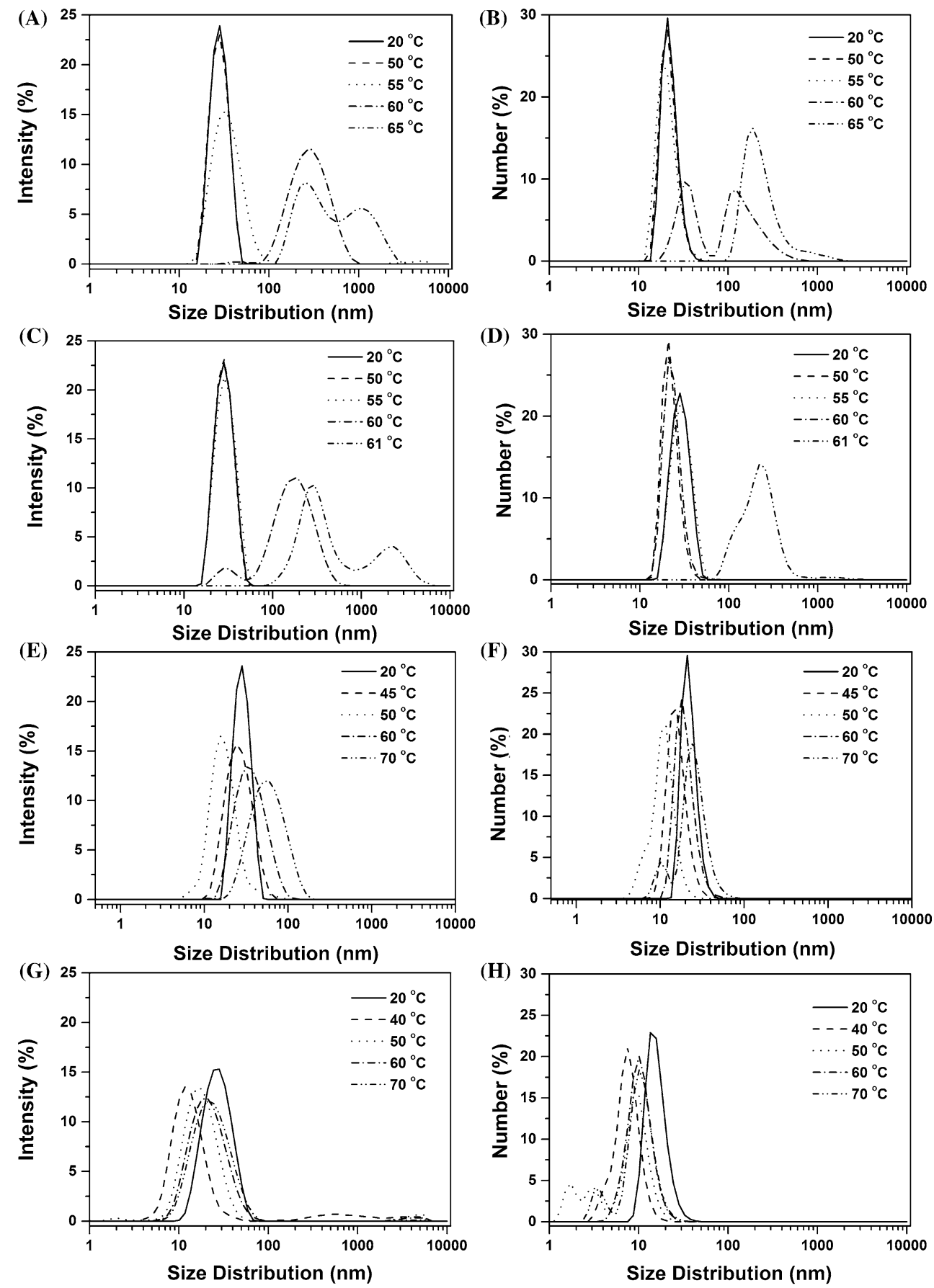

as assigned by a $D_{\mathrm{H}}$ value of $25 \mathrm{~nm}$, at $20{ }^{\circ} \mathrm{C}$ (Table 1 ; Figs. $1 \mathrm{~b}, 2 \mathrm{~g}, \mathrm{~h})$. The increase of temperature at $\mathrm{pH} 9.0$ promotes the broadening and shifting of intensity distribution curves to lower diameter values at $40^{\circ} \mathrm{C}$, in agreement with the oxy-HbRa oligomeric dissociation (Fig. $2 \mathrm{~g}$ ). At higher temperatures, a small increase in the species sizes in solution is observed, without aggregation, consistent with the inhibition of the aggregation process by oxy-HbRa oligomeric dissociation (Fig. 2g). The corresponding particle number distribution curves also show a broadening and shifting of the curves to lower sizes, in agreement with the protein oligomeric dissociation at $50{ }^{\circ} \mathrm{C}$ and a contribution of smaller species around $4-5 \mathrm{~nm}$ is observed, probably due to the monomer subunit dissociated in solution. Furthermore, no evidence of aggregate formation at higher temperature is observed (Fig. 2h). At pH 8.0, the intensity distribution curves show that oligomeric dissociation of HbRa starts at $45{ }^{\circ} \mathrm{C}$, with a shift of the curves to lower sizes (Fig. 2e), but the dissociation process is less pronounced as compared to $\mathrm{pH} 9.0$ (Fig. $2 \mathrm{~g}$, e). However, at 
higher temperatures of 60 and $70{ }^{\circ} \mathrm{C}$, the unfolding of protein takes place accompanied by a shift to high size values as well as a broadening of the intensity distribution curves (Fig. 2e). The intensity and number distribution curves show the contribution of unfolded protein at $70{ }^{\circ} \mathrm{C}$, displaying a shift to high diameter values (Fig. 2f).

In Table S1 (Supporting material), the peak width at half height and polydispersity (PDI) values obtained from the intensity distribution curves (Fig. 2) are shown. In the $\mathrm{pH}$ range of 5.0-8.0, the peak width and PDI values are quite similar, corresponding to native oxy-HbRa in solution, being $18 \mathrm{~nm}$ and $0.02-0.03$ at $20{ }^{\circ} \mathrm{C}$ (Table S1). In acidic and neutral $\mathrm{pH}$, these values remain practically constant up to $50{ }^{\circ} \mathrm{C}$, while for alkaline $\mathrm{pH}$ values 8.0 and 9.0 they change significantly at 45 and $20{ }^{\circ} \mathrm{C}$, respectively. Above $60{ }^{\circ} \mathrm{C}$, at acidic and neutral $\mathrm{pH}$ values, both the peak width and PDI show a significant increase due to protein denaturation and aggregation (Table S1). For alkaline $\mathrm{pH}$ values 8.0 and 9.0, the peak width values are significantly lower as compared to acidic and neutral values, consistent with a partial oxy-HbRa oligomeric dissociation and reduction of aggregation. Previous studies on the urea effects on oxyHbGp stability have shown that the oligomeric dissociation inhibits significantly the effective protein aggregation (Carvalho et al. 2015). It is worth mentioning that the high values of peak widths for the intensity distributions at acidic and neutral $\mathrm{pH}$ values is also probably associated with the relatively long heating cycle performed in melting experiments, where the samples were exposed to the whole cycle for at least $20 \mathrm{~h}$. This long heating cycle would avoid possible kinetic effects in the aggregation/denaturation process.

\section{Oxy-HbRa thermal stability in the pH range of 5.0-9.0 by SAXS}

\section{Neutral $p H 7.0$}

The experimental SAXS curves and corresponding fitting curves obtained by the GNOM program for oxy-HbRa $3.0 \mathrm{mg} / \mathrm{ml}$ at $\mathrm{pH} 7.0$ as a function of temperature are presented in Fig. 3a. The corresponding distance distribution function curves, $p(r)$, are presented in Fig. 3b. All parameters obtained by GNOM analyses are collected in Table 2. Oxy-HbRa at $20^{\circ} \mathrm{C}$ shows SAXS curve characteristic of the native form (Carvalho et al. 2012, 2014b), presenting three shoulders centered at q values of $0.04,0.07$, and $0.12 \AA^{-1}$, respectively (Fig. 3a) and bell-shaped $p(r)$ distribution function, consistent with native globular protein (Fig. 3b).

Oxy-HbRa, at pH 7.0, upon increasing the temperature, remains stable up to $50{ }^{\circ} \mathrm{C}$, since both the SAXS curves and the parameters $R_{\mathrm{g}}$ and $D_{\max }$ do not change, as compared to those at $20{ }^{\circ} \mathrm{C}$ (Table 2; Fig. 3a, b). However, at $60{ }^{\circ} \mathrm{C}$, oxy-HbRa displays $R_{\mathrm{g}}$ and $D_{\max }$ parameters of
$138 \pm 2$ and $550 \pm 20 \AA$, respectively, suggesting the presence of denatured/aggregated protein in solution (Table 2). Moreover, the $R_{\mathrm{g}}$ values obtained by Guinier approximation for oxy-HbRa in the temperature range of $20-60{ }^{\circ} \mathrm{C}$ at pH 7.0 remain similar (121-130 ̊) considering the error values (Table 3 ). The corresponding $p(r)$ function (Fig. $3 \mathrm{~b}$ ) displays two particle contributions, the first one centered at $150 \AA$ is probably associated with a mixture of whole native and aggregated protein, and the second one (tail), centered around $350 \AA$, assigned, probably, to some elongated and/or extended species that could be totally denatured/aggregated oxy-HbRa (Fig. 3b). Similar observations for oxy-HbGp have been made in a recent study on the interaction of the protein with CTAC surfactant (Carvalho et al. 2014b). The contribution of some fraction of the whole native oxy-HbRa in the $p(r)$ function, the partial observation of the shoulders in the SAXS curve and the constancy of the $I(0)$ parameter, at $60{ }^{\circ} \mathrm{C}$, all together suggest that this temperature is not enough to completely denature the protein (Table 2; Fig. 3a).

\section{Acidic pH media}

For acidic $\mathrm{pH} 5.0$, oxy-HbRa at $20{ }^{\circ} \mathrm{C}$ displays SAXS curve and $p(r)$ function distribution (Fig. 3c, d) similar to those at $\mathrm{pH} 7.0$, with $R_{\mathrm{g}}$ and $D_{\max }$ parameters characteristic of native form (Table 2). An increase of temperature to $50{ }^{\circ} \mathrm{C}$ does not produce any change in the $R_{\mathrm{g}}$ and $D_{\max }$ parameters, displaying values of $108 \pm 1$ and $300 \pm 10 \AA$, respectively, suggesting that the protein denaturation at $\mathrm{pH}$ 5.0 is similar as compared to $\mathrm{pH} 7.0$ (Table 2). A slight decrease in the $p(r)$ function intensity is observed. At $60{ }^{\circ} \mathrm{C}$, the $p(r)$ function also displays a slight contribution at higher $r$ values, smaller than that at $\mathrm{pH}$ 7.0, and assigned, probably, as due to some amount of partially unfolded protein and denatured/aggregated oxy-HbRa, in the extended and/or elongated form (Fig. $3 \mathrm{~d}$ ). $R_{\mathrm{g}}$ and $D_{\max }$ parameters are slightly higher than those observed at $\mathrm{pH} 7.0$, confirming the existence of aggregation at $\mathrm{pH} 5.0$. At $\mathrm{pH}$ 6.0, oxy-HbRa presents similar SAXS curves and $p(r)$ functions, and the denaturation starts at $50{ }^{\circ} \mathrm{C}$, but $R_{\mathrm{g}}$ and $D_{\max }$ parameters display higher values, as compared to $\mathrm{pH} 5.0$ (Table 2). The $R_{\mathrm{g}}, D_{\max }$ and $I(0) \mathrm{SAXS}$ parameters present a significant increase at $60{ }^{\circ} \mathrm{C}$, in agreement with the denaturation/aggregation of the protein. The significant increase of $I(0)$ together with a considerable residual positive value of the $p(r)$ function at the higher limit of $r$ value are quite characteristic of protein aggregation (see Fig. S1 in Supporting material). $R_{\mathrm{g}}$ values obtained by Guinier approximation for oxy-HbRa, at pH 5.0 and 6.0, do not show significant changes, varying from $110 \pm 14$ to $129 \pm 16 \AA$, in the temperature range of $20-60{ }^{\circ} \mathrm{C}$ (Table 3 ), in agreement with GNOM analysis (Table 2). 
Fig. 3 Experimental smallangle $\mathrm{X}$-ray scattering curves (symbols) for oxy-HbRa at $3.0 \mathrm{mg} / \mathrm{ml}$ in acetate-phosphateborate buffer $30 \mathrm{mmol} / \mathrm{l}$, a at $\mathrm{pH} 7.0, \mathbf{c}$ at $\mathrm{pH} 5.0, \mathbf{e}$ at $\mathrm{pH} 8.0$, and $\mathbf{g}$ at $\mathrm{pH} 9.0$, as a function of temperature, with the respective fits (full lines) obtained from the GNOM program. The distance distribution functions $p(r)$, $\mathbf{b}$ at $\mathrm{pH} 7.0, \mathbf{d}$ at $\mathrm{pH} 5.0, \mathbf{f}$ at $\mathrm{pH} 8.0$, and $\mathbf{h}$ at $\mathrm{pH} 9.0$, obtained from the GNOM program are shown
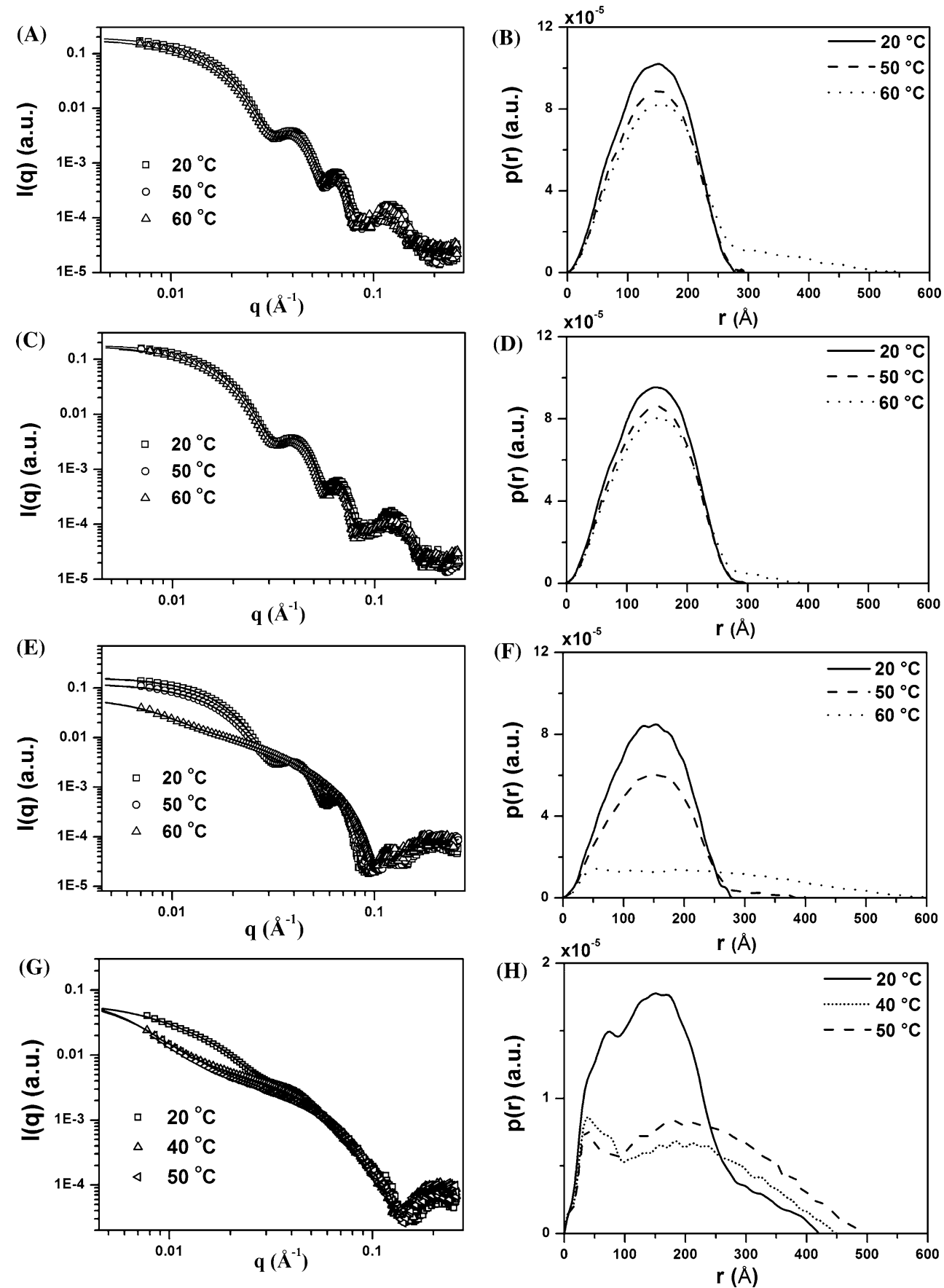

\section{Alkaline pH media}

At $\mathrm{pH}$ 8.0, the oxy-HbRa, $20{ }^{\circ} \mathrm{C}$, presents a SAXS curve consistent with the native form (Fig. 3e), as observed at $\mathrm{pH}$ 7.0, while at $\mathrm{pH} 9.0$, the three shoulders are not so well defined and the scattering intensity $I(\mathrm{q})$ is reduced for oxy$\mathrm{HbRa}$ (Fig. 3g). Moreover, oxy-HbRa, at pH 8.0, $20{ }^{\circ} \mathrm{C}$, presents radius of gyration $\left(R_{\mathrm{g}}\right)$ and maximum dimension $\left(D_{\max }\right)$ parameters values of $108 \pm 1$ and $300 \pm 10 \AA$, which are characteristic of the whole protein in solution (Table 2) and very similar to those obtained for $\mathrm{HbGp}$ (Carvalho et al. 2012). $p(r)$ function at $\mathrm{pH} 8.0,20^{\circ} \mathrm{C}$, shows a single particle contribution, with a bell-shaped form, typical of folded HbRa form (Fig. 3f). However, oxy-HbRa, at pH 9.0, $20^{\circ} \mathrm{C}$, shows higher $R_{\mathrm{g}}$ and $D_{\max }$ values (Table 2), as compared to the native form, at $\mathrm{pH} 7.0,5.0$, and 8.0, which, together with a modified $p(r)$ (Fig. 3h), are consistent with the presence of partially dissociated and unfolded protein in solution.

At alkaline $\mathrm{pH} 8.0$, the increase of temperature to $60{ }^{\circ} \mathrm{C}$ promotes the disappearance of the shoulders in the SAXS 
Table $2 R_{\mathrm{g}}(\AA), D_{\max }(\AA)$ and $I(0)$ (a.u.) SAXS parameters values, obtained from the GNOM program analyses, for oxy-HbRa, $3.0 \mathrm{mg} / \mathrm{ml}$, in the $\mathrm{pH}$ range of 5.0-9.0, and at the indicated temperature values
Table $3 R_{\mathrm{g}}(\AA), I_{0}$, and $N$ (number of points in the fit) parameter values, obtained from Guinier plots, for oxy-HbRa, $3.0 \mathrm{mg} / \mathrm{ml}$, SAXS curves, in the $\mathrm{pH}$ range of 5.0-9.0, and at the indicated temperature values

\begin{tabular}{lllllll}
\hline$T\left({ }^{\circ} \mathrm{C}\right)$ & Parameters & $\mathrm{pH} 5.0$ & $\mathrm{pH} 6.0$ & $\mathrm{pH} 7.0$ & $\mathrm{pH} 8.0$ & $\mathrm{pH} 9.0$ \\
\hline 20 & $R_{\mathrm{g}}$ & $109 \pm 1$ & $108 \pm 1$ & $108 \pm 1$ & $108 \pm 1$ & $124 \pm 2$ \\
& $D_{\max }$ & $300 \pm 10$ & $300 \pm 10$ & $300 \pm 10$ & $300 \pm 10$ & $420 \pm 20$ \\
& $I(0)$ & $0.19 \pm 0.01$ & $0.20 \pm 0.01$ & $0.21 \pm 0.01$ & $0.17 \pm 0.02$ & $0.05 \pm 0.02$ \\
50 & $R_{\mathrm{g}}$ & $108 \pm 1$ & $112 \pm 1$ & $109 \pm 1$ & $112 \pm 1$ & $151 \pm 2$ \\
& $D_{\max }$ & $300 \pm 10$ & $350 \pm 10$ & $300 \pm 10$ & $350 \pm 10$ & $450 \pm 20$ \\
& $I(0)$ & $0.17 \pm 0.01$ & $0.18 \pm 0.01$ & $0.18 \pm 0.01$ & $0.13 \pm 0.01$ & $0.03 \pm 0.02$ \\
60 & $R_{\mathrm{g}}$ & $114 \pm 1$ & $175 \pm 8$ & $138 \pm 2$ & $190 \pm 2$ & $170 \pm 3$ \\
& $D_{\max }$ & $400 \pm 15$ & $650 \pm 15$ & $550 \pm 20$ & $600 \pm 15$ & $500 \pm 20$ \\
& $I(0)$ & $0.16 \pm 0.01$ & $0.24 \pm 0.02$ & $0.19 \pm 0.02$ & $0.07 \pm 0.02$ & $0.03 \pm 0.02$ \\
\hline
\end{tabular}

The reported error values correspond to standard deviation for independent fits of the experimental SAXS curves in a $D_{\max }$ value range around $10 \%$ of the optimal value

\begin{tabular}{lllllll}
\hline$T\left({ }^{\circ} \mathrm{C}\right)$ & Parameters & $\mathrm{pH} 5.0$ & $\mathrm{pH} 6.0$ & $\mathrm{pH} 7.0$ & $\mathrm{pH} 8.0$ & $\mathrm{pH} 9.0$ \\
\hline 20 & $R_{\mathrm{g}}$ & $110 \pm 14$ & $114 \pm 9$ & $121 \pm 24$ & $111 \pm 11$ & $156 \pm 40$ \\
& $I_{0}$ & 0.193 & 0.209 & 0.216 & 0.171 & 0.057 \\
& $N$ & 8 & 8 & 5 & 7 & 4 \\
50 & $R_{\mathrm{g}}$ & $120 \pm 16$ & $118 \pm 18$ & $128 \pm 28$ & $125 \pm 23$ & $201 \pm 53$ \\
& $I_{0}$ & 0.191 & 0.194 & 0.202 & 0.139 & 0.042 \\
& $N$ & 8 & 8 & 5 & 7 & 4 \\
60 & $R_{\mathrm{g}}$ & $129 \pm 16$ & $127 \pm 20$ & $130 \pm 33$ & $183 \pm 55$ & $192 \pm 50$ \\
& $I_{0}$ & 0.192 & 0.206 & 0.192 & 0.059 & 0.045 \\
& $N$ & 8 & 8 & 5 & 7 & 4 \\
\hline
\end{tabular}

$\mathrm{Rg}$ values at $\mathrm{pH} 9.0$, obtained from Guinier plots, are not consistent with the limit $q^{*} R_{\mathrm{g}}$ less than 1 . In fact even for the lowest q point a value of $q^{*} R_{\mathrm{g}}$ of 1.3 is obtained. See text for more detail curves, characteristic of oxy-HbRa native form, suggesting oligomeric dissociation (Fig. 3e). On the other hand, the $p(r)$ function does not show clearly small particle contribution, is spread over a larger range of $r$ values, and $R_{\mathrm{g}}$ and $D_{\max }$ present an increase as a function of temperature (Table 2; Fig. 3f). At $60{ }^{\circ} \mathrm{C}$, the $p(r)$ function shows a very small bump at lower $r$ side that could be due to some dissociated protein fragment, while the broad contribution extended over a larger $r$ range seems to be due to aggregates (insert, Fig. 3f). This could be due to the fact that the increase of temperature to $60^{\circ} \mathrm{C}$ leads to an overlap of the partial oligomeric dissociation and denaturation/aggregation processes in the system. The $I(0)$ parameter value is reduced at the highest temperature as compared to the temperature range of $20-50{ }^{\circ} \mathrm{C}$, which also might indicate that the aggregation at $\mathrm{pH} 8.0$ and $60{ }^{\circ} \mathrm{C}$ is just starting.

At $\mathrm{pH} 9.0$, oxy-HbRa is probably partially dissociated and unfolded already at $20{ }^{\circ} \mathrm{C}$ (Fig. $3 \mathrm{~g}$ ), since $R_{\mathrm{g}}$ and $D_{\max }$ values are $124 \pm 2$ and $420 \pm 20 \AA$, respectively (Table 2), the shoulders are practically unresolved, and the $I(0)$ value is quite reduced as compared to the $\mathrm{pH}$ range of 5.0-8.0. The $p(r)$ function is changed significantly, as compared to $\mathrm{pH}$ 8.0: the presence of small molecular weight protein fragments is clearly seen as a bump in the curve at lower $r$ values together with some contribution above $300 \AA$, which is probably due to denatured elongated protein (Fig. 3h). The increase of temperature accelerates both the oligomeric dissociation and denaturation as well as the aggregation of oxy-HbRa, where at $60{ }^{\circ} \mathrm{C}$ a complete disappearance of shoulder in SAXS curve and distortion of $p(r)$ function are observed (Fig. $3 \mathrm{~g}, \mathrm{~h}$ ) and $R_{\mathrm{g}}$ and $D_{\max }$ increase substantially (Table 2; Fig. 3h). The $p(r)$ functions at $\mathrm{pH}$ values 8.0 and 9.0 show that oxy-HbRa presents a strong tendency to aggregate, as compared to the results observed by SAXS for oxy-HbGp (Carvalho et al. 2012). The large contribution of aggregated species indicates that the oligomeric dissociation and unfolding processes for oxy-HbRa and oxy$\mathrm{HbGp}$ are not identical. Since the heating procedures used in SAXS experiments were different, and the samples were not heated for a long time as in the DLS measurements ("Oxy-HbRa thermal stability in the $\mathrm{pH}$ range of 5.0-9.0 by DLS" section), it is quite possible that kinetic effects in the aggregation/denaturation process would make it difficult to directly compare the DLS and SAXS data. Nevertheless, it is quite clear that the size values obtained at $20{ }^{\circ} \mathrm{C}$ by both techniques are consistent. 
Fig. 4 Kratky plots for oxy-HbRa, at $3.0 \mathrm{mg} / \mathrm{ml}$, in acetate-phosphate-borate buffer $30 \mathrm{mmol} / \mathrm{l}$, at different temperatures, monitoring protein conformational changes. a At $\mathrm{pH} 7.0, \mathbf{b}$ at $\mathrm{pH} 5.0, \mathbf{c}$ at $\mathrm{pH} 8.0$, and $\mathbf{d}$ at $\mathrm{pH} 9.0$, respectively
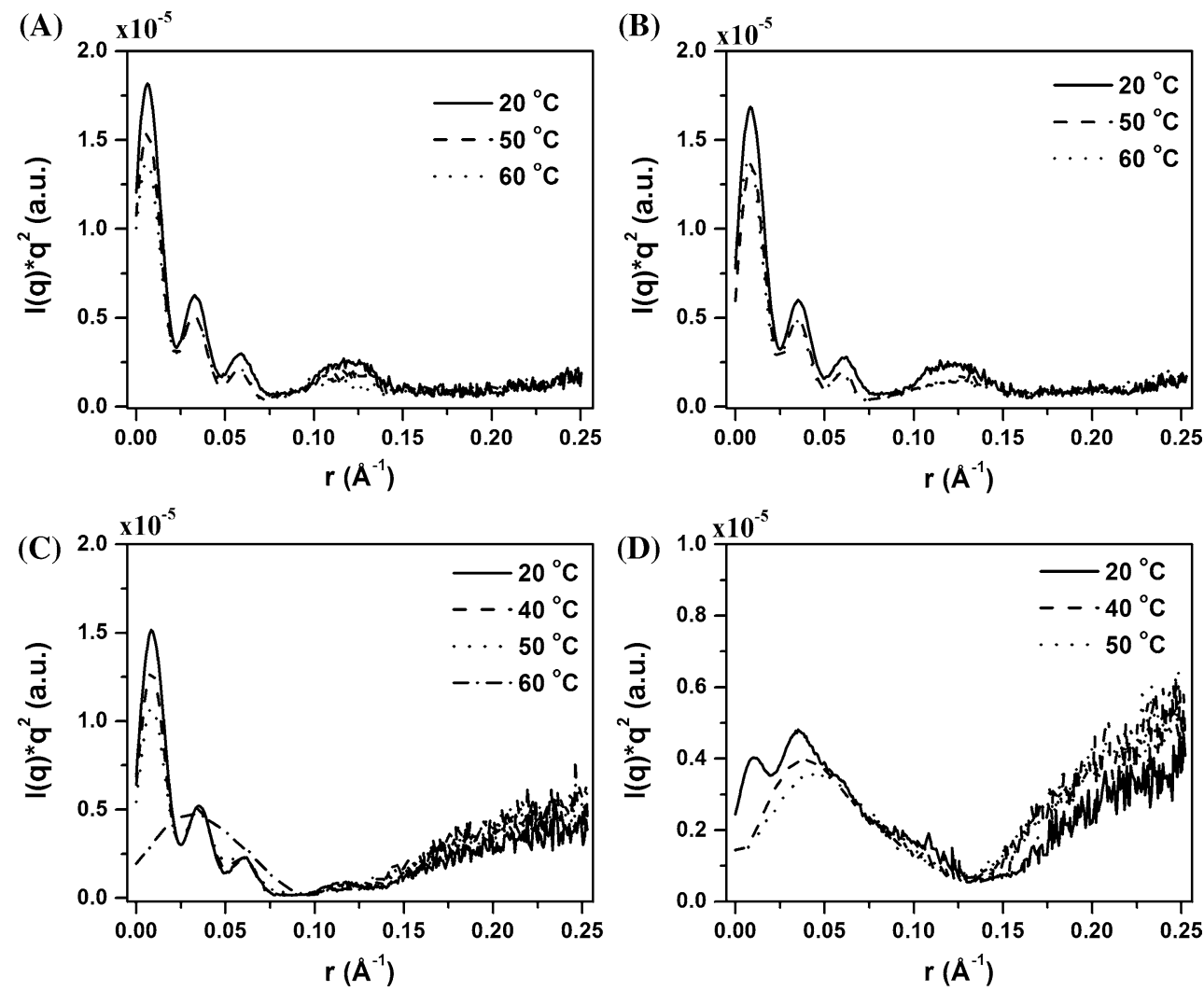

$R_{\mathrm{g}}$ values obtained by Guinier approximation present a clear expression of partial protein aggregation, quite sensitive to the $\mathrm{pH}$ value, 8.0 or 9.0. At $\mathrm{pH} 8.0$, a significant increase of $R_{\mathrm{g}}$ takes place only at $60{ }^{\circ} \mathrm{C}$, while at $\mathrm{pH} 9.0$, already at $20{ }^{\circ} \mathrm{C}$, the value of $R_{\mathrm{g}}$ is increased to $183 \AA$. Moreover, at $\mathrm{pH} 9.0$, aggregation takes place in the whole temperature range (Table 3 ). In Table 3, the parameters $I_{0}$ and the number of points $(N)$ used in the fits are also shown. It is worthy of notice that the 5 initial points used in the Guinier plots at $\mathrm{pH}$ values $5.0-8.0$ (q range of $0.00702-0.00991 \mathrm{~A}^{-1}$ ) are all in the range of $q^{*} R_{\mathrm{g}}$ either lower or equal to the limit of 1 . At $\mathrm{pH} 9.0$ the lowest $\mathrm{q}$ value $\left(0.00847 \mathrm{~A}^{-1}\right)$ already gives a $q^{*} R_{\mathrm{g}}$ value of 1.3. This is probably associated to the protein aggregation at $\mathrm{pH} 9.0$.

Kratky plots for oxy-HbRa, in the $\mathrm{pH}$ range of 5.0-9.0, as a function of temperature

In order to obtain further insight on the structural changes induced by temperature in oxy-HbRa, Kratky plots were made from the SAXS data (Fig. 4a). The characteristic shoulders of folded oxy-HbRa at $20{ }^{\circ} \mathrm{C}$, at $\mathrm{pH}$ values 7.0 and 5.0, are observed (Fig. 4a, b). The increase of temperature induces a decrease in the shoulder intensity at $60{ }^{\circ} \mathrm{C}$, consistent with protein denaturation. However, the temperature of $60{ }^{\circ} \mathrm{C}$ is not enough to promote the complete oxy-HbRa denaturation since the shoulders pattern remains in the Kratky plots (Fig. 4a, b).

Oxy-HbRa at $\mathrm{pH} 8.0,20^{\circ} \mathrm{C}$, shows a Kratky plot with characteristic shoulders of folded protein while at $\mathrm{pH} 9.0$ less intense shoulders are observed (Fig. 4c, d), as compared to $\mathrm{pH}$ values 7.0 (Fig. 4a) and 5.0 (Fig. 4b). At pH 8.0, $60{ }^{\circ} \mathrm{C}$, the shoulders disappear completely (Fig. 4c). This dramatic change of pattern might be associated with protein oligomeric dissociation and denaturation. Furthermore, the loss of shoulders at lower $q$ values is accompanied by an increase in intensity of Kratky plots above $0.15 \AA^{-1}$, at $\mathrm{pH}$ values 8.0 and 9.0 , which is assigned to protein structural changes, such as inter-domain correlation and intra-molecular polypeptide re-arrangements, due to the unfolding process (Carvalho et al. 2014a, b; Hirai et al. 1999).

Previous studies reported for oxy-HbGp in the presence of cationic CTAC surfactant (Carvalho et al. 2014b) show similar Kratky plots patterns as a function of temperature, as compared to oxy-HbRa data shown in our present work (Fig. 4). These studies display a decrease in the shoulders for folded oxy-HbGp in acidic, neutral, and alkaline media, with increase of temperature, assigned to protein dissociation and denaturation in solution. 

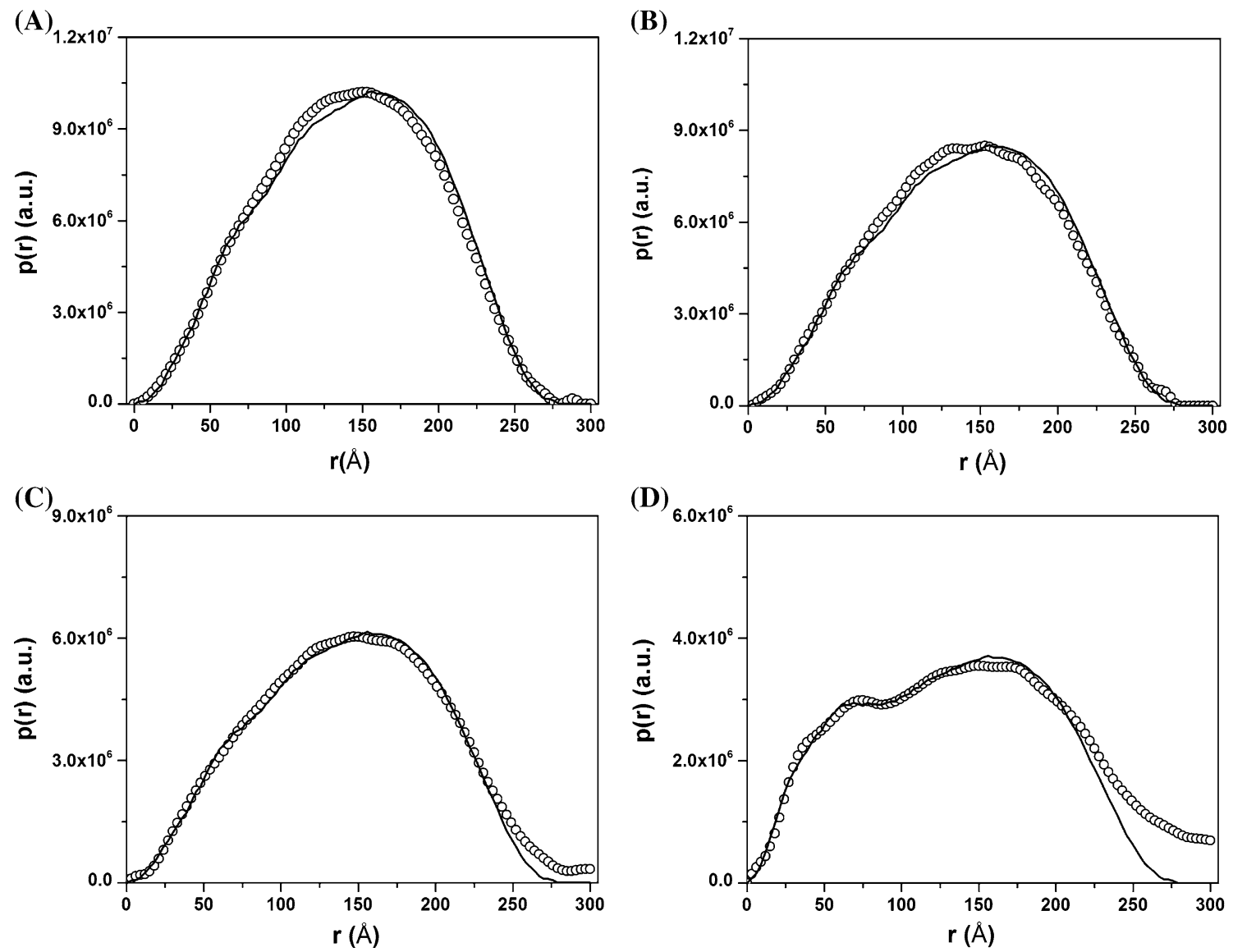

Fig. 5 Electronic density distributions as a function of distance, $p(r)$, obtained from GNOM for HbRa experimental scattering curves (Fig. 3) together with the best fit considering the $p(r)$ of the theoretical scattering curves of the high-resolution subunits from $\mathrm{HbGp}$

\section{Theoretical SAXS curves obtained from the Protein Data Bank (PDB) for $\mathrm{HbGp}$}

Theoretical SAXS curves (Fig. S2) were obtained for Glossoscolex paulistus hemoglobin (oxy-HbGp) coordinate data deposited in the Protein Data Bank (PDB) under ID code 4U8U (Bachega et al. 2015) by using CRYSOL software (Konarev et al. 2006). The architecture of the full particle of $3.6 \mathrm{MDa}$ is based on two hexagonal disks in which the most prominent substructure corresponds to one-twelfth of the whole particle (a protomer), which is composed of a dodecamer of globins, $(a b c d)_{3}$, together with three non-globin chains named linkers, $L_{1}, L_{2}$, and $L_{3}$ (Fig. S2). Therefore, assuming a high similarity of the three-dimensional structure between oxy-HbRa and oxy-HbGp, the theoretical SAXS curves of the different subunits of oxyHbRa were obtained based on the deposited coordinates for oxy-HbGp (Bachega et al. 2015). The theoretical scattering curves obtained from the PDB structure were further analyzed by the GNOM software to produce the corresponding deposited in the Protein Data Bank under ID code 4U8U (Bachega et al. 2015). a pH 7.0, $20{ }^{\circ} \mathrm{C} ; \mathbf{b} \mathrm{pH} 8.0,20{ }^{\circ} \mathrm{C} ; \mathbf{c}$ pH $8.0,50{ }^{\circ} \mathrm{C} ; \mathbf{d} \mathrm{pH}$ $9.0,20{ }^{\circ} \mathrm{C}$

theoretical $p(r)$ functions used in the analysis of our experimental SAXS data for oxy-HbRa.

Analysis of oligomeric dissociation, denaturation, and aggregation of oxy-HbRa

In Fig. S2, the theoretical scattering curves for oxy-HbGp fragments along with the corresponding $p(r)$ functions (see inserts) are shown. The curves were split into three parts for clarity, emphasizing the greater (Figs. S2A and S2B) and smaller (Fig. S2C) molecular mass subunits. The scattering intensities are not normalized and correspond to the mass relations. Moreover, the $p(r)$ functions are normalized by the corresponding factor, assuming an $\mathrm{HbGp}$ stoichiometry of $12(a b c d)_{3} L_{3}$ for the whole oligomer. The $p(r)$ and $I(q)$ (Fig. S2) theoretical curves were used to fit experimental HbRa $p(r)$ function based on the linear combination and $I(q)$ scattering curves using OLIGOMER program (Figs. 5, S3).

In Fig. 5a, b, the $p(r)$ functions for oxy-HbRa, at $\mathrm{pH}$ values 7.0 and $8.0,20^{\circ} \mathrm{C}$, respectively, are shown with 
Table 4 Percentage contributions of fragments of the whole protein obtained from linear combination of corresponding theoretical $p(r)$ curves of $\mathrm{HbGp}$ as a $\mathrm{pH}$ function at indicated temperatures

\begin{tabular}{|c|c|c|c|c|c|c|c|c|}
\hline \multirow[t]{3}{*}{ Fragments } & \multicolumn{8}{|c|}{ Percentage contributions (\%) } \\
\hline & \multirow{2}{*}{ 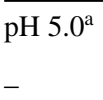 } & \multicolumn{3}{|c|}{ pH 6.0} & \multirow{2}{*}{$\begin{array}{l}\mathrm{pH} 7.0^{\mathrm{a}} \\
-\end{array}$} & \multicolumn{2}{|l|}{$\mathrm{pH} 8.0$} & \multirow{2}{*}{$\begin{array}{l}\text { pH } 9.0 \\
20{ }^{\circ} \mathrm{C}\end{array}$} \\
\hline & & $20^{\circ} \mathrm{C}$ & $50^{\circ} \mathrm{C}$ & $60{ }^{\circ} \mathrm{C}$ & & $20^{\circ} \mathrm{C}$ & $50^{\circ} \mathrm{C}$ & \\
\hline WholeHbGp $12(\boldsymbol{a b c d})_{3} \boldsymbol{L}_{3}$ & 100 & 100 & $95 \pm 4$ & $88 \pm 4$ & 100 & 100 & $66 \pm 10$ & $16 \pm 4$ \\
\hline Hexamer $6(\boldsymbol{a b c d})_{3} L_{3}$ & - & - & - & - & - & - & & - \\
\hline Protomer $(\boldsymbol{a b c d})_{3} \boldsymbol{L}_{3}$ & - & - & $5 \pm 2$ & - & - & - & & - \\
\hline Dodecamer $(\boldsymbol{a b c d})_{3}$ & - & - & - & - & - & - & $12 \pm 5$ & $26 \pm 7$ \\
\hline Tetramer $(\boldsymbol{a b c d})$ & - & - & - & $12 \pm 5$ & - & - & $22 \pm 7$ & $58 \pm 15$ \\
\hline
\end{tabular}

At high temperatures, such as $60^{\circ} \mathrm{C}$ at $\mathrm{pH} 8.0$ and $40{ }^{\circ} \mathrm{C}$ and $50{ }^{\circ} \mathrm{C}$ at $\mathrm{pH} 9.0$, fits were not successful, due to the large contribution of aggregates species

a The percentage contributions were $100 \%$ of whole $\mathrm{HbGp}$ for all temperatures the corresponding fits, giving a contribution of $100 \%$ of native whole protein, similar to that reported for oxy-HbGp (Carvalho et al. 2012). These results are in agreement with previous studies by optical absorption, fluorescence, and light scattering intensity (LSI) spectroscopies that show oxy-HbRa in native format these $\mathrm{pH}$ values. For oxy-HbRa, $\mathrm{pH} 8.0$, at $50{ }^{\circ} \mathrm{C}$ (Fig. 5c), the best fit was obtained with three different species, $66 \pm 10 \%$ of native whole protein $\left(12(a b c d)_{3} L_{3}\right), 12 \pm 5 \%$ of dodecamer $(a b c d)_{3}$ and $22 \pm 7 \%$ of tetramer $(a b c d)$ (Table 4 ; Fig. $5 c$ ). The equilibrium composition, at $\mathrm{pH} 8.0,60^{\circ} \mathrm{C}$, was not obtained, probably due to the large contribution of aggregated species in the experimental distance distribution function (see Fig. 3f), and the fact that the theoretical $p(r)$ for aggregated species is unavailable. This effect is also observed at $\mathrm{pH}$ 9.0 for the temperatures of 40 and $50{ }^{\circ} \mathrm{C}$ (Fig. 3h).

For alkaline $\mathrm{pH} 9.0$, at $20^{\circ} \mathrm{C}$, our fit also shows the contribution of three species, namely $16 \pm 4 \%$ of native whole protein, $26 \pm 7 \%$ of dodecamer, and $58 \pm 15 \%$ of tetramer (Fig. 5d). Therefore, at $\mathrm{pH} 9.0$, already at $20{ }^{\circ} \mathrm{C}$ the contribution of native whole protein is reduced as compared to $\mathrm{pH}$ 8.0. At pH 8.0 and $60{ }^{\circ} \mathrm{C}$, as well as at $\mathrm{pH} 9.0$ and 40 and $50{ }^{\circ} \mathrm{C}$, the $p(r)$ functions (Fig. $3 \mathrm{f}, \mathrm{h}$ ) present a significant reduction in intensity and broadening to larger $r$ values range. We believe this is associated with the formation of oxy-HbRa aggregates at these $\mathrm{pH}$ and temperatures values, making our analysis of the SAXS data in terms of isolated contributions of protein species not possible. Some modeling of these aggregates in future work could be quite interesting.

It is worth mentioning that our results for oxy-HbRa presented here have some common features but are not identi$\mathrm{cal}$, as compared to recent studies reported for oxy-HbGp (Carvalho et al. 2012). These studies have shown only the contribution of native oxy-HbGp, at pH 7.0 and $8.0,20{ }^{\circ} \mathrm{C}$, similar to the observed for oxy-HbRa (our Table 4). For $\mathrm{pH}$ $8.0,60{ }^{\circ} \mathrm{C}$, oxy-HbGp, presented $2 \pm 1 \%$ of hexamer that corresponds to half of the whole protein, $6 \times(a b c d)_{3} L_{3}$, $48 \pm 13 \%$ of dodecamer $(a b c d)_{3}$ and $50 \pm 43 \%$ of tetramer.
The fitting for the $p(r)$ distribution function obtained from the experimental scattering curve for oxy-HbRa in acidic $\mathrm{pH}$ values 5.0 and 6.0 (fitting not shown) and the corresponding data are reported in Table 4 . At $20{ }^{\circ} \mathrm{C}$, a contribution of $100 \%$ of native protein, for both $\mathrm{pH}$ values, was the best fit. However, for oxy-HbRa at $\mathrm{pH} 6.0,50{ }^{\circ} \mathrm{C}$, our best fit shows the following contributions in the solution: $5 \pm 2 \%$ of protomer $(a b c d)_{3} L_{3}$ and $95 \pm 4 \%$ of native whole protein, while at $\mathrm{pH} 6.0,60^{\circ} \mathrm{C}, 12 \pm 5 \%$ of tetramer $(a b c d)$ and $88 \pm 4 \%$ of native whole protein, respectively, was obtained (Table 4). As expected, an increase of temperature from 50 to $60^{\circ} \mathrm{C}$ produces an increase in low molecular weight species. These results are again different, as compared to HbGp (Carvalho et al. 2012), where in acidic $\mathrm{pH}$ values the protein is very stable towards oligomeric dissociation being more prone to aggregation, as compared to our present results for oxy-HbRa.

In Fig. S3, the fit by OLIGOMER program for oxy$\mathrm{HbRa}$ at $\mathrm{pH} 7.0$, at $20{ }^{\circ} \mathrm{C}$, is shown. A single contribution of $100 \%$ of native protein obtained in this fit is in agreement with non-linear fitting from $p(r)$ function. For $\mathrm{pH}$ values 5.0 and 6.0 , at $20^{\circ} \mathrm{C}$, similar fits to the $\mathrm{pH} 7.0$ (data not shown) were obtained. However, reasonable fits for oxy-HbRa partially dissociated/aggregated at $\mathrm{pH}$ values $6.0,8.0$, and 9.0 by the OLIGOMER program were not obtained. Two factors might contribute to the failure of OLIGOMER analyses: the first one is due to the large contribution of the whole protein and/or aggregated species, as compared to that from dissociated smaller subunits. The second one is related to the low scattering intensity of these smaller subunits making it difficult to resolve them in the scattering curves analyses. The OLIGOMER program seems to be more sensitive to the presence of aggregates in solution, as compared to the fits using the $p(r)$ function. Since oxy-HbGp does not produce aggregates together with oligomeric dissociation, the fits at $\mathrm{pH}$ values 8.0 and 9.0, using the OLIGOMER program were successful for this system (Carvalho et al. 2012). 


\section{Conclusions}

The present studies by DLS show that oxy-HbRa, at acidic and neutral $\mathrm{pH}$ values, undergoes denaturation and aggregation, accompanied by partial sedimentation of the aggregates. In acidic $\mathrm{pH}$ values, sedimentation of aggregates, observed above $60{ }^{\circ} \mathrm{C}$, makes it difficult to evaluate the sizes at the highest temperature of $70{ }^{\circ} \mathrm{C}$. Differently from oxy-HbGp (Carvalho et al. 2012; Santiago et al. 2007), oxy-HbRa does not undergo partial oligomeric dissociation before denaturation/aggregation for both $\mathrm{pH}$ values 5.0 and 7.0, but at $\mathrm{pH} 6.0$ some partial dissociation takes place. At alkaline $\mathrm{pH}$ values 8.0 and 9.0, the increase of temperature promotes oxy-HbRa partial oligomeric dissociation before denaturation, and, at $60{ }^{\circ} \mathrm{C}$, aggregation is quite significant. Our results suggest that oxy-HbRa is more resistant to temperature-induced oligomeric dissociation and more prone to aggregation in the whole $\mathrm{pH}$ range used in this work. SAXS data show that oxy-HbRa remains native at $20{ }^{\circ} \mathrm{C}$ in the $\mathrm{pH}$ range of 5.0-8.0. Oxy-HbRa, at $\mathrm{pH}$ values 5.0, 6.0, and 7.0, is partially denatured at $60{ }^{\circ} \mathrm{C}$. This partial denaturation at acidic and neutral $\mathrm{pH}$ values is probably due to the experimental relatively short heating times used in SAXS experiments, as compared to DLS. For alkaline $\mathrm{pH}$ 8.0, the increase of temperature induces $\mathrm{HbRa}$ partial oligomeric dissociation before denaturation. At $\mathrm{pH}$ 9.0, $20{ }^{\circ} \mathrm{C}$, oxy-HbRa is partially dissociated and unfolded, as shown by the $R_{\mathrm{g}}$ and $D_{\max }$ parameters. Increase of temperature produces an overlap of dissociation and denaturation/aggregation processes in the system, with inhibition of dissociation and increase in aggregation. The semi-quantitative analysis of oligomeric dissociation of oxy-HbRa, based on the theoretical fragments of the oxy-HbGp crystal structure, shows a contribution of smaller species in solution, namely, protomer $\left((a b c d)_{3} \mathrm{~L}_{3}\right)$, dodecamer $(a b c d)_{3}$ and tetramer $(a b c d)$. The increase in $\mathrm{pH}$ and temperature values leads to an increase of small molecular weight species contribution and a decrease of the whole protein. Finally, oxy-HbRa is more stable than oxy-HbGp, regarding both temperature and $\mathrm{pH}$-induced effects, since the HbRa-quantified dissociated species present higher mass as compared to Glossoscolex paulistus hemoglobin under similar solution conditions.

Acknowledgments The authors are grateful to the National Synchrotron Light Laboratory (LNLS), Campinas, Brazil, for making available the SAXS beam line used in these studies. Thanks are also due to the Brazilian agencies FAPESP, CNPq, and CAPES for partial financial support. F.A.O. Carvalho is a recipient of a post-doctoral grant from FAPESP (2013/09829-8). J.W.P. Carvalho is grateful for a post-doctoral grant from FAPESP (2013/09349-6) and M. Tabak is grateful to CNPq for a research grant. The authors are indebted to Prof. Dr. Carlos Ernesto Salmon Garrido, from Faculdade de Filosofia Ciências e Letras de Ribeirão Preto (FFCLRP), Universidade de São Paulo, for help with the analysis of linear combination of $p(r)$ functions. The authors are also indebted to Dr. José Fernando Ruggiero Bachega for the help with the production of HbGp fragments from crystallographic structure used in the $p(r)$ simulations as well as in Scheme 1. Thanks are also due to Mr. Ezer Biazin for efficient support in sample preparations.

\section{References}

Bachega JFR (2013) Estrutura cristalográfica da hemoglobina de Glossoscolex paulistus, um complexo de 3.6 mega Daltons (Crystallographic structure of Glossoscolex paulistus Hemoglobin, A complex of 3.6 MDa). Universidade de São Paulo, Instituto de Física de São Carlos (IFSC) (165 pp. Ph.D. Thesis (in Portuguese))

Bachega JFR, Bleicher L, Horjales ER, Santiago PS, Garratt RC, Tabak M (2011) Crystallization and preliminary structural analysis of the giant haemoglobin from Glossoscolex paulistus at 3.2 angstrom. J Synchrotron Radiat 18:2-28

Bachega JFR, Maluf FV, Andi B, Pereira HD, Carazzollea MF, Orville A, Tabak M, Garratt RC, Horjales E (2015) The crystallographic structure of the giant hemoglobin from Glossoscolex paulistus hemoglobin at 3.2 angstrom resolution. Acta Crystallogr D71:1257-1271. ID code 4U8U

Carvalho FAO, Carvalho JWP, Santiago PS, Tabak M (2011) Further characterization of the subunits of the giant extracellular hemoglobin of Glossoscolex paulistus (HbGp) by SDS-PAGE electrophoresis and MALDI-TOF-MS. Process Biochem 46:2144-2151

Carvalho JWP, Santiago PS, Batista T, Salmon CEG, Barbosa LRS, Itri R, Tabak M (2012) On the temperature stability of extracellular hemoglobin of Glossoscolex paulistus, at different oxidation states: SAXS and DLS studies. Biophys Chem 163-164:44-55

Carvalho JWP, Carvalho FAO, Santiago PS, Tabak M (2013) Thermal denaturation and aggregation of hemoglobin of Glossoscolex paulistus in acid and neutral media. Int J Biol Macromol 54:09-118

Carvalho FAO, Carvalho JWP, Biazin E, Santiago PS, Tabak M (2014a) Characterization of Rhinodrilus alatus hemoglobin $(\mathrm{HbRa})$ and its subunits: evidence for strong interaction with cationic surfactants DTAB and CTAC. Comp Biochem Physiol Part B 167:23-29

Carvalho JWP, Carvalho FAO, Batista T, Santiago PS, Tabak M (2014b) Cetyltrimethylammonium chloride (CTAC) effect on the thermal stability of oxy-HbGp: dynamic light scattering (DLS) and small angle X-ray scattering (SAXS) studies. Colloids Surf B 118:14-24

Carvalho FAO, Alves FR, Carvalho JWP, Tabak M (2015) Guanidine hydrochloride and urea effects upon thermal stability of Glossoscolex paulistus hemoglobin (HbGp). Int J Biol Macromol 74:18-28

Desbruye ÁD, Laubier L (1982) Paralvinella grasslei, new genus, new species of Alvinellidae (Polycheata: ampharetidae) from the Galapagos Rift geothermal vents. Proc Biol Soc Wash 95:484-494

Glatter O, Kratky O (1982) Small angle X-ray scattering. Academic Press, London

Guinier A, Fournet G (1955) Small angle scattering of X-ray. Wiley, New York

Hirai M, Arai S, Iwase H (1999) Complementary analysis of thermal transition multiplicity of hen egg-white lysozyme at low $\mathrm{pH}$ using X-ray scattering and scanning calorimetry. J Phys Chem B 103:549-556

Jernshøj KD, Hassing S, Olsen LF (2013) A combination of dynamic light scattering and polarized resonance Raman scattering applied in the study of Arenicola Marina extracellular hemoglobin. J Chem Phys 139:139-142 
Konarev PV, Petoukhov MV, Volkov VV, Svergun DI (2006) ATSAS 2.1, a program package for small-angle scattering data analysis. $\mathrm{J}$ Appl Cryst 39:277-286

Krebs A, Lamy J, Vinogradov SN, Zipper P (1998) Lumbricus terrestris hemoglobin: a comparison of small angle X-ray scattering and cryoelectron microscopy data. Biopolymers 45:289-298

Lamy JN, Green BN, Toulmond A, Wall JS, Weber RE, Vinogradov SN (1996) The giant haxagonal bilayer extracellular hemoglobins. Chem Rev 96:3113-3124

Mertens HDT, Svergun DI (2010) Structural characterization of proteins and complexes using small-angle X-ray solution scattering. J Struct Biol 172(1):128-141

Oliveira MS, Moreira LM, Tabak M (2007) Partial characterization of giant extracellular hemoglobin of Glossoscolex paulistus: a MALDI-TOF-MS study. Int J Biol Macromol 40:429-436

Pecora R (1985) Dynamic light scattering. Plenum Press, New York, pp $1-420$

Poli AL, Moreira LM, Hidalgo AA, Imasato H (2005) Autoxidation studies of extracellular hemoglobin of Glossoscolex paulistus at pH 9: cyanide and hydroxyl effect. Biophys Chem 114:253-260

Putnam CD, Hammel M, Hura GL, Tainer JA (2007) X-ray solution scattering (SAXS) combined with crystallography and computation: defining accurate macromolecular structures, conformations and assemblies in solution. Q Rev Biophys 40:191-285

Rousselot M, Le Guen D, Chabasse C, Zal F (2006) Novel dissociation mechanism of a polychaetous annelid extracellular hemoglobin. FEBS J 273:1582-1596

Royer WE, Zhu H, Gorr TA, Flores JF, Knapp JE (2005) Allosteric hemoglobin assembly: diversity and similarity. J Biol Chem 280:27477-27480

Royer WE, Sharma H, Strand K, Knapp JE, Bhyravbhatla B (2006) Lumbricus erythrocruorin at 3.5 angstrom resolution: architecture of a megadalton respiratory complex. Structure 14:1167-1177

Santiago PS, Moreira LM, de Almeida EV, Tabak M (2007) Giant extracellular Glossoscolex paulistus Hemoglobin (HbGp) upon interaction with cetyltrimethylammonium chloride (CTAC) and sodium dodecyl sulphate (SDS) surfactants: dissociation of oligomeric structure and autoxidation. Biochim Biophys Acta 1770:506-517
Santiago PS, Moura F, Moreira LM, Domingues MM, Santos N, Tabak M (2008) Dynamic light scattering and optical absorption spectroscopy study of $\mathrm{pH}$ and temperature stabilities of the extracellular hemoglobin of Glossoscolex paulistus. Biophys J 94:2228-2240

Santiago PS, Carvalho FAO, Domingues MM, Carvalho JWP, Santos NC, Tabak M (2010a) Isoelectric point determination for Glossoscolex paulistus extracellular hemoglobin: oligomeric stability in acidic $\mathrm{pH}$ and relevance to protein-surfactant interactions. Langmuir 26:9794-9801

Santiago PS, Carvalho JWP, Domingues MM, Santos NC, Tabak M (2010b) Thermal stability of extracellular hemoglobin of Glossoscolex paulistus: determination of activation parameters by optical spectroscopic and differential scanning calorimetric studies. Biophys Chem 152:128-138

Svergun DI (1991) Mathematical methods in small-angle scattering data analysis. J Appl Cryst 24:485-492

Tabak M, Carvalho FAO, Carvalho JWP, Bachega JFR, Santiago PS (2012) Recent new characterizations on the giant extracellular hemoglobin of Glossoscolex paulistus and some other giant hemoglobins from different worms. In: Innocenti A (ed) Stoichiometry and research-the importance of quantity in biomedicine, vol 1. Intech Open Science, Croatia, pp 337-356

Vinogradov SN (2004) The stoichiometry of the four linker subunits of Lumbricus terrestris hemoglobin suggests an asymmetric distribution. Micron 35:127-129

Weber RE, Vinogradov SN (2001) Nonvertebrate hemoglobins: functions and molecular adaptations. Physiol Rev 81:570-611

Zal F, Rousselot M (2014) Extracellular hemoglobins from annelids, and their potential use in biotechnology. In: La Barre S, JeanMichel K (eds) Outstanding marine molecules: chemistry, biology, analysis, 1st edn. Wiley, Weinheim, pp 361-376

Zal F, Green BN, Martineu P, Lallier FH, Toulmond A, Vinogradov SN, Childress JJ (2000) Polypeptide chain composition diversity of hexagonal-bilayer hemoglobins within a single family of annelids, the Alvinellidae. Eur J Biochem 267:5227-5236 